\title{
Targeted ablation of the PTH/PTHrP receptor in osteocytes impairs bone structure and homeostatic calcemic responses
}

\author{
William F Powell Jr, Kevin J Barry, Irena Tulum, Tatsuya Kobayashi, Stephen E Harris ${ }^{1}$, \\ F Richard Bringhurst and Paola Divieti Pajevic \\ Endocrine Unit, Massachusetts General Hospital and Harvard Medical School, Thier 1101, 50 Blossom Street, Boston, Massachusetts 02114, USA \\ ${ }^{1}$ Department of Periodontics, University of Texas Health Science Center School of Dentistry, San Antonio, Texas 78299, USA \\ (Correspondence should be addressed to P Divieti Pajevic; Email: divieti@helix.mgh.harvard.edu)
}

\begin{abstract}
Parathyroid hormone $(\mathrm{PTH})$ is a major physiologic regulator of calcium, phosphorous, and skeletal homeostasis. Cells of the osteoblastic lineage are key targets of PTH action in bone, and recent evidence suggests that osteocytes might be important in the anabolic effects of PTH. To understand the role of PTH signaling through the PTH/PTHrP receptors (PPR) in osteocytes and to determine the role(s) of these cells in mediating the effects of the hormone, we have generated mice in which PPR expression is specifically ablated in osteocytes. Transgenic mice in which the $10 \mathrm{~kb}-D m p 1$ promoter drives a tamoxifen-inducible Cre-recombinase were mated with animals in which exon 1 of PPR is flanked by lox-P sites. In these animals, osteocyte-selective PPR knockout $\left(\mathrm{Ocy}-\mathrm{PPR}{ }^{\mathrm{cKO}}\right.$ mice) could be induced by administration of
\end{abstract}

tamoxifen. Histological analysis revealed a reduction in trabecular bone and mild osteopenia in Ocy-PPR ${ }^{\mathrm{cKO}}$ mice. Reduction of trabeculae number and thickness was also detected by micro-computed tomography analysis whereas bone volume fraction (BV/TV\%) was unchanged. These findings were associated with an increase in Sost and sclerostin expression. When Ocy-PPR ${ }^{\mathrm{cKO}}$ mice were subjected to a low-calcium diet to induce secondary hyperparathyroidism, their blood calcium levels were significantly lower than littermate controls. Moreover, PTH was unable to suppress Sost and sclerostin expression in the Ocy-PPR ${ }^{\mathrm{cKO}}$ animals, suggesting an important role of PTH signaling in osteocytes for proper bone remodeling and calcium homeostasis.

Journal of Endocrinology (2011) 209, 21-32

\section{Introduction}

Osteocytes are the most abundant cells in bone, outnumbering osteoblasts by 10 -fold and osteoclasts by $1000-$ fold (Aguirre et al. 2006), and yet their function is still incompletely understood. Osteocytes act as mechanosensors of bone, and recent evidence has indicated a role for these cells in bone modeling and remodeling and phosphate homeostasis (Feng et al. 2006, Lorenz-Depiereux et al. 2006, Tatsumi et al. 2007). Studies on osteocytes have been hampered by the inaccessibility of these cells and by the lack of molecular and cell surface markers that could be used to isolate and characterize them. In the last decade, however, our knowledge of osteocytes has expanded dramatically, mostly as a result of the identification of several selective osteocytic markers, such as dentin matrix protein 1 (DMP1; George et al. 1994, Ye et al. 2004, Yang et al. 2005), matrix extracellular phosphoglycoprotein/osteocyte-factor 45 (MEPE/OF45; Petersen et al. 2000, Gowen et al. 2003), membrane-type matrix metalloproteinase (MT1-MMP; Holmbeck et al. 1999, 2005), phosphate regulating endopeptidase homolog (PHEX; Westbroek et al. 2002, Liu et al. 2006), and sclerostin
(Sost; Winkler et al. 2003, van Bezooijen et al. 2004) that have allowed, for the first time, a more direct analysis of the molecular and cellular biology of osteocytes.

Osteocytes express receptors for several extracellular ligands, including the parathyroid hormone (PTH) type 1 receptor (PPR; Fermor \& Skerry 1995), estrogen receptors (both $\alpha$ and $\beta$; Ehrlich et al. 2002, Jessop et al. 2004, Lanyon et al. 2004, Lee et al. 2004), prostaglandin receptor $\left(\mathrm{EP}_{2}\right)$, and a novel, as yet uncloned, receptor that specifically recognizes the carboxyl-terminal region of PTH, the carboxyl-terminal PTH receptor (Divieti et al. 2001, 2005).

PTH, a single-chain polypeptide comprised of 84 amino acids, is synthesized and secreted by the parathyroid glands in a calcium-regulated manner. PTH maintains serum calcium homeostasis and controls renal phosphate reabsorption and vitamin D $1 \alpha$-hydroxylation. PTH modulates bone turnover by actions that are mediated by a $G$ protein-coupled receptor, the PPR (Juppner et al. 1991). The PPR is highly expressed in bone and kidney, but is also found in a variety of other tissues not regarded as classical PTH targets. This likely reflects the local paracrine role of PTHrP in tissues such as breast, skin, heart, blood vessels, and others. The N-terminal 34 amino 
acids of PTH are necessary and sufficient to fully activate the PPR, which, in turn, can activate multiple $G$ protein-coupled pathways, including those that signal through $\mathrm{cAMP} /$ protein kinase A, phospholipase C (PLC)/protein kinase $\mathrm{C}$ (PKC), and nonPLC-dependent PKC and $\mathrm{Ca}^{2+}{ }_{\mathrm{i}}$.

It has been shown that PTH can prevent apoptosis of osteocytes (and osteoblasts) and that this mechanism may contribute to the anabolic action of intermittently administered PTH (Jilka et al. 1998, 1999). Moreover, recent studies from O'Brien et al. (2006) revealed a critical role of PTH (and PPR) in osteocytes. They generated transgenic mice expressing a constitutively active PPR specifically in osteocytes by placing the H223R mutant receptor (Schipani et al. 1995, 1997) under the control of the $8 \mathrm{~kb}-D m p 1$ promoter (named DMP1-caPTHR1). In these mice, the levels of Sost mRNA in bone were threefold lower than wild-type littermates at 8 weeks of age. Strikingly, DMP1-caPTHR 1 mice also exhibited a $42 \%$ and an $84 \%$ increase in bone mineral density (BMD) in the spine and femur respectively as determined by dual-energy X-ray absorptiometry (DEXA) (O'Brien et al. 2006), suggesting an important role for $\mathrm{PPR} / \mathrm{cAMP}$-mediated pathways in the anabolic effect of PTH.

With this in mind, we aimed to specifically ablate the PPR in osteocytes to directly assess the role of receptor activation in these cells. We have generated transgenic mice in which the 10-kb promoter of Dmp1 drives a tamoxifen-inducible bacteriophage Cre-recombinase. These mice were crossed with mice in which exon 1 of the PPR gene was flanked by lox-P sites to generate animals that specifically lack PPRs in osteocytes. Initial histological analysis demonstrated that lack of PPR expression in osteocytes induces a reduction in trabecular bone, accompanied by a tonic elevation of Sost and sclerostin and a lack of PTH-induced Sost and sclerostin suppression.

Moreover, ablation of PPR in osteocytes impairs skeletal responses to a low-calcium diet, indicating a critical role of this receptor in controlling calcium homeostasis.

\section{Materials and Methods}

\section{Generation of the $10 \mathrm{~kb}$-Dmp1-Cre-ERT2 mice}

The 14-kb Dmp1 promoter fragment $(-9624 \sim+4439)$ - containing a 9624-bp promoter region, a 95-bp exon 1 (E1), 4326-bp intron 1, and 17-bp initial non-coding region of exon 2 (E2) - was cloned into the Cre-ERT2-LacZ-MH vector, which contains the Cre-ERT2 DNA. The Dmp1Cre-ERT2 transgene was released from the vector backbone with the use of the unique restriction enzymes NotI and SalI, purified by Qiaquick gel extraction kit (Qiagen), quantified, and microinjected into the pronucleus of B6C3F1 hybrid mice (Taconic, Hudson, NY, USA) to generate founder mice. Injections were performed on site at the Massachusetts General Hospital transgenic core facility (CBRC MGH mouse facility). Three rounds of pronuclear injections were performed, and a total of 68 offspring were obtained. Eighteen pups died at birth, and 14 of the remaining 50 were positive for Cre-recombinase integration (23\%), as assessed by genomic PCR of tail DNA using Cre-specific primers (Fig. 1B). Six independent transgenic founders were mated with wild-type C57BL/6 mice, and the F1 offspring were analyzed. All transgenic lines produced pups at the expected 1:1 ratio, and the pups appeared normal, grew indistinguishably from wild-type, and were fertile. To further analyze the characteristics of these mice, a Southern blot analysis of genomic DNA was performed. A Crerecombinase-specific probe was cloned using PCR primers, as shown in Fig. 1A. Genomic DNA was digested using the restriction enzyme EcoRI that cleaves the insert in one site, and Southern blot analysis confirmed the germline transmission and single site of insertion. In addition, to assess that the transgene was transmitted through generations, Southern blot analysis of genomic DNA from F2 progenies was performed, as shown in Supplementary Figure 1, see section on supplementary data given at the end of this article.

PPR-floxed mice were described previously (Kobayashi et al. 2005). $10 \mathrm{~kb}-D m p 1-C r e-E R T 2$ mice were crossed with homozygous PPR-floxed $\left(\mathrm{PPR}^{\mathrm{f} / \mathrm{fl}}\right)$ mice to obtain doubly heterozygous mice $10 \mathrm{~kb}-D m p 1-C r e-E R T 2: \mathrm{PPR}^{\mathrm{f} /+}$, which were in turn mated with $\mathrm{PPR}^{\mathrm{f} / \mathrm{fl}}$ to obtain the desired $10 \mathrm{~kb}-D m p$ 1-Cre-ERT2:PPR ${ }^{\mathrm{f} / \mathrm{fl}}$, or osteocyte-selective PPR knockout $\left(\mathrm{Ocy}-\mathrm{PPR}^{\mathrm{cKO}}\right)$, mice and littermates which include $10 \mathrm{~kb}-$ Dmp 1-Cre-ERT2:PPR ${ }^{\mathrm{fl} /+}, \mathrm{PPR}^{\mathrm{fl} / \mathrm{fl}}$, and $\mathrm{PPR}^{\mathrm{f} /+}$, all of which were used as controls in all experiments. We crossed the Dmp1-Cre-ERT2 mice with ROSA26R mice (Soriano 1999), kindly provided by Dr Henry Kronenberg (Massachusetts General Hospital, Boston, MA, USA), to obtain the ROSA26R and Dmp1-Cre-ERT2 double transgenic mice for monitoring Cre-recombinase expression. For tamoxifen injections, $10 \mathrm{mg}$ of free base tamoxifen (MPBio, Solon, OH, USA) was dissolved in $100 \mu \mathrm{l}$ of dimethylformamide (Fisher Scientific, Waltham, MA, USA) and then diluted to $10 \mathrm{mg} / \mathrm{ml}$ in corn oil (Sigma). Mice were injected with $50-150 \mu$, depending on their age.

\section{Genotyping of mice}

The genotypes of the mice were determined by PCR analysis of genomic DNA extracted from tail biopsies. For the $10 \mathrm{~kb}-D m p 1-C r e-E R T 2$ transgene, the forward Cre primer $\left(5^{\prime}\right.$-CGCGGTCTGGCAGTAAAAACTATC- $\left.3^{\prime}\right)$ and the reverse Cre primer $\left(5^{\prime}\right.$-CCCACCGTCAGTACGTGAGATATC- $3^{\prime}$ ) were used to generate a PCR product of $\sim 400 \mathrm{bp}$. For the floxed PPR allele, the P1 primer $\left(5^{\prime}\right.$-ATG AGG TCT GAG GTA CAT GGC TCT GA-3') and the P2 primer (5'-CCT GCT GAC CTC TCT GAA AGA ATG T- $\left.3^{\prime}\right)$ were used, which recognized the sequence spanning the $3^{\prime}$ lox-P site, as previously reported (Kobayashi et al. 2002). Wild-type and mutant alleles give $\sim 210$ and $290 \mathrm{bp}$ products respectively. Mice were primarily kept in mixed genetic backgrounds with dominance of the C57/B16, and all 


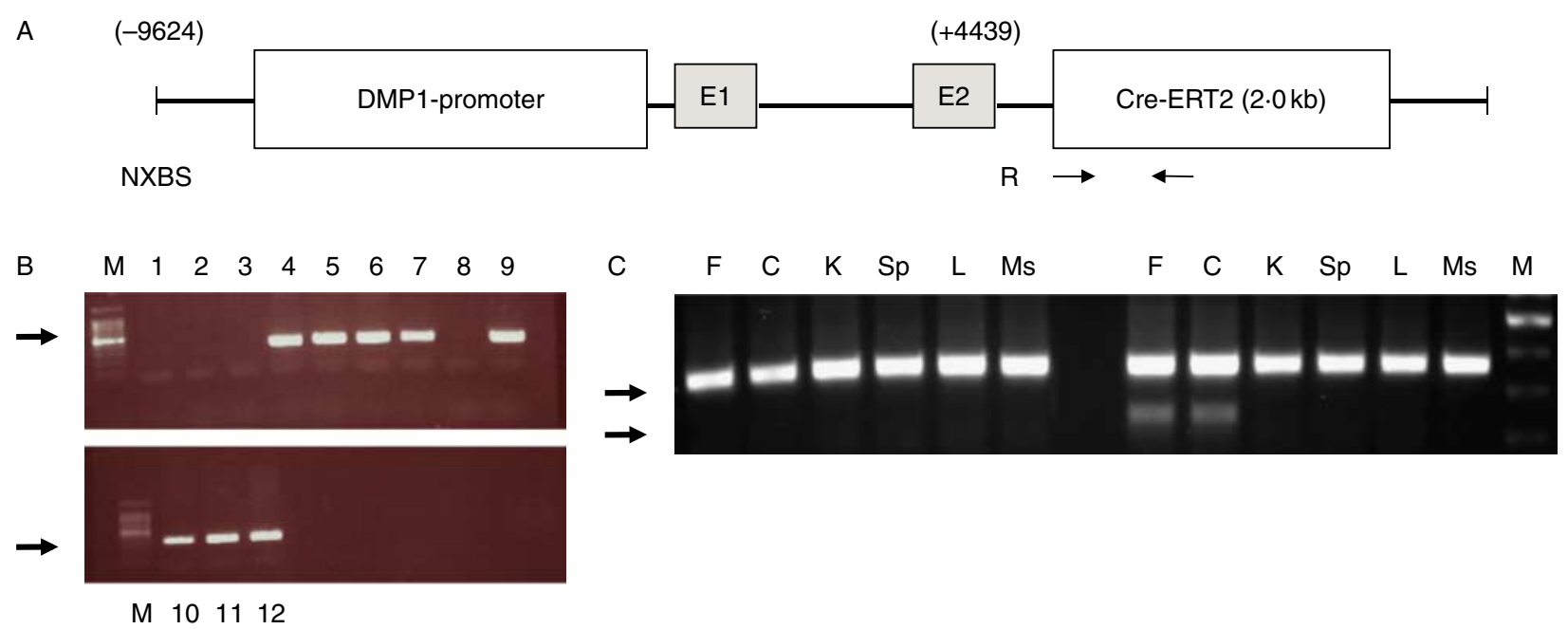

Figure 1 Generation of $10 \mathrm{~kb}-\mathrm{DMP} 1-C r e-E R T 2$ mice. (A) The $9.6 \mathrm{~kb}$ of DMP1 was cloned into the SK plasmid. NXBS and R are unique restriction sites. N, Notl; X, Xbe; B, BmH; S, Smal; R, EcoRI. The vector was released by Notl-Sall digestion. E1 and E2 are exon 1 and the portion of exon 2 before the ATG initiation site respectively. Arrows indicate approximate sites of PCR primers for Cre-recombinase. (B) Genomic DNA from founders was assessed for integration of Cre-recombinase by PCR using primers specific for the Cre-ERT2 region (arrows). Genomic DNA from the second round of pronuclear injections is shown. Eight mice were positive for Cre-recombinase (lanes 4-7, 9-12). $M=100$ bp ladder. $\mathrm{H}=$ no DNA control (water). Arrows indicate the expected Cre product (size 300 bp). (C) Allele-specific DNA recombination PCR in control (left lines) and Ocy-PPR ${ }^{\text {cKO }}$ (right lines) mice. A specific band $(\sim 600)$ is present only in femur (F) and calvaria (C) of Ocy-PPR ${ }^{\mathrm{CKO}}$. The presence of the larger band $(\sim 1.5 \mathrm{~kb})$ is due to contamination with other bone cells (i.e. bone marrow cells, osteoblasts, and osteoclasts) that were not removed during DNA preparation. As shown here, there was no recombination in kidney (K), spleen (Sp), liver (L), or muscle (Ms). M=100 bp marker. Full colour version of this figure available via http://dx.doi.org/10.1530/ JOE-10-0308.

experiments were performed with littermates as controls. Procedures that involved mice were approved by the Institutional Animal Care and Use Committee, Subcommittee on Research Animal Care, at Massachusetts General Hospital.

Allele-specific DNA recombination was performed on DNA isolated from long bones (femurs), calvaria, kidney, liver, skeletal muscle, and spleen. Briefly, pups were treated with tamoxifen (400-500 $\mu \mathrm{g})$ at days $3,5,7,14$, and 21. Mice were killed at 3 weeks of age by $\mathrm{CO}_{2}$ inhalation, tissues were quickly removed, and DNA was isolated following standard protocol. Multiplex PCR analysis was performed using allelespecific primers, P1, P2, and P3 (5'-ACA TGG CCA TGC CTG GGT CTG AGA-3') and following the manufacturer protocol (Qiagen Multiplex PCR kit, Qiagen).

\section{Histology and immunohistochemistry}

Tissues were fixed in $10 \%$ formalin/PBS solution at $4{ }^{\circ} \mathrm{C} \mathrm{ON}$, decalcified in 20\% EDTA pH 8 for 7-15 days, processed, embedded in paraffin, and sectioned. Sections were stained with hematoxylin and eosin, or used for immunohistochemistry. In some experiments, undecalcified femurs were embedded in methyl methacrylate (Aldrich Chemical Co, Milwuakee, WI, USA). Sections were cut using a diamondembedded wire saw, and then stained by the Von Kossa method. Sclerostin expression was detected immunohistochemically using commercially available biotinylated anti-mouse sclerostin antibody (1:50 dilution; R\&D Systems, Inc., Minneapolis, MN, USA) and diaminobenzidine detection (Vector, Burlingame, CA, USA). Briefly, sections were deparaffinized, and endogenous peroxidase activity was inhibited by $3 \% \mathrm{H}_{2} \mathrm{O}_{2}$ treatment for $15 \mathrm{~min}$. Subsequently, slides were blocked with tris- $\mathrm{NaCl}$ blocking buffer (TSA Biotin Tyramide kit, Perkin Elmer, Waltham, MA, USA) for $30 \mathrm{~min}$ at room temperature and then incubated for $1 \mathrm{~h}$ with biotinylated anti-mouse sclerostin antibody. After extensive rinsing, sections were incubated for $30 \mathrm{~min}$ with streptavidin (SA)-conjugated HRP and tyramide following the manufacturer's protocol (TSA Biotin Tyramide kit) and developed with a $3,3^{\prime}$-diaminobenzidine substrate chromogen system (Vector Laboratories).

\section{Serology}

Blood was collected by tail vein bleeding for ionized calcium and by carotid transection or retro-orbital bleeding for serum collection. Ionized calcium was measured by the Ciba-Corning $634 \mathrm{Ca}^{2+} / \mathrm{pH}$ analyzer (Ciba-Corning Diagnostics Corp., Medfield, MA, USA). Intact immunoreactive PTH was measured in duplicate using ELISA (Immutopics, Inc., San Clemente, CA, USA). Serum mouse TRAP5B (Mouse TRAP Assay), PINP, and CTX (Rat-LAPS EIA) were measured in duplicate using ELISA (Immunodiagnostic Systems Ltd, Boldon, UK). Statistical analysis was performed using the Student's $t$-test, and $P$ values $<0.05$ were accepted as significant. 


\section{Low-calcium diet and PTH injections}

In some experiments, mice were fed a low-calcium diet $(0 \cdot 02 \%$ calcium, $0 \cdot 4 \%$ phosphorous, Teklad, Harlan, Madison, WI, USA) for 2 weeks prior to calcium measurement. Mice were injected s.c. with $300 \mu \mathrm{g} / \mathrm{kg}$ of human PTH (1-34; MGH Peptide Core Facility). Blood was collected by tail bleeding for ionized calcium measurement before and $1 \mathrm{~h}$ after PTH injections using a $\mathrm{Ca}^{2+} / \mathrm{pH}$ analyzer.

\section{$R N A$ extraction and purification}

RNA was isolated from long bones of Ocy-PPR ${ }^{\mathrm{cKO}}$ mice and littermate controls following sequential collagenase and EDTA digestions to remove endosteal and periosteal osteoblasts and bone marrow cells. For detailed protocol, see Supplementary Methods, see section on supplementary data given at the end of this article. Femurs were washed with $1 \mathrm{ml}$ of RNA-later solution (Ambion, Austin, TX, USA) prior to RNA isolation by Trizol. RNA was extracted from the bone by homogenizing it in Trizol (Invitrogen) using a tissue homogenizer for $1 \mathrm{~min}$ on ice. The RNA was then extracted from the homogenate according to the manufacturer's recommendations. RNA quality and quantity were ascertained by u.v. spectrophotometry (NanoDrop 8000, Thermo Fisher, Waltham, MA, USA).

\section{Quantitative reverse transcription- $P C R$}

Reverse transcription was performed on $0 \cdot 5-1 \mu \mathrm{g}$ of DNAsetreated total RNA and oligoDT primers using Omniscript (Invitrogen) according to the manufacturer's instructions. Quantitative PCR (qPCR) was performed using the QuantiTect SYBR Green PCR kit (Qiagen) and the DNA Engine Opticon 2 qPCR system (MJ Research, Inc., Waltham, MA, USA). The comparative method, using the $-\Delta \Delta C_{\mathrm{T}}$ formula, was used to determine the RNA relative expression, with glyceraldehyde-3-phosphate dehydrogenase (GAPDH) being used for normalizing. Statistical analysis was performed using the Student's $t$-test, and $P$ values $<0.05$ were accepted as significant. Primer sequences are described in Supplementary Methods, see section on supplementary data given at the end of this article.

\section{cAMP measurement}

Tibiae were isolated from 4- to 6-week-old mice. Briefly, tibiae were dissected and cleaned of adherent tissues. Distal and proximal epiphyses were removed, and the bone marrow was flushed out using 2-3 $\mathrm{ml}$ of ocMEM supplemented with $0 \cdot 1 \%$ BSA and $25 \mathrm{mM}$ HEPES ( $\mathrm{pH} 7 \cdot 4)$. The remaining diaphyseal-enriched region of the bones was cut into three pieces and sequentially digested as described above for RNA isolation. Each piece was then placed in ice-cold cAMPassay buffer (DMEM containing $10 \mathrm{mM}$ HEPES, $0 \cdot 1 \%$ heat-inactivated BSA, and $1 \mathrm{mM}$ isobutylmethylxantine). Bone pieces were then incubated in cAMP-assay buffer with the appropriate treatment at $37^{\circ} \mathrm{C}$ for $15 \mathrm{~min}$. The three pieces of each tibia were incubated with vehicle alone (assay buffer), $100 \mathrm{nM}$ human PTH (1-34), or 0.1 $\mu \mathrm{M}$ forskolin. At the end of the incubation, the reaction was terminated by quickly removing the bones and placing them in $0.3 \mathrm{ml}$ of cold 90\% 2-propanol in $0.5 \mathrm{M} \mathrm{HCl}$. Bones were then incubated for $16-18 \mathrm{~h}$ at $4{ }^{\circ} \mathrm{C}$. Propanol extraction was repeated, and the combined extracts were evaporated by vacuum centrifugation. The dried extracts were redissolved in acetate buffer $(50 \mathrm{mM} \mathrm{Na}$ acetate $/ 0 \cdot 05 \% \mathrm{Na}$ azide, $\mathrm{pH} 6 \cdot 2$ ) for measurement of cAMP by a specific RIA, as previously described (Divieti et al. 2005). Bones were washed twice with $0.5 \mathrm{ml}$ acetone and once with $0.5 \mathrm{ml}$ ether and were air-dried and weighed. The results were normalized for the bone weight, and the data were expressed as picomole of cAMP produced per mg of dry bone. Each experiment was repeated at least three times.

\section{Fluorescence-activated cell sorting analysis}

In some experiments, homozygous Dmp1-GFP transgenic mice (provided by Drs Ivo Kalajzic and David W Rowe, University of Connecticut Health Center, Hartford, CN, USA) were crossed with $\mathrm{PPR}^{\mathrm{fl} / \mathrm{fl}}$ mice to generate Ocy-PPR ${ }^{\mathrm{cKO}}$ and WT mice that express green fluorescent protein (GFP) under the $8 \mathrm{~kb}-D m p 1$ promoter. Calvarial cells obtained from mice exhibiting the same genotype were pooled, and GFP-expressing cells (enriched in osteocytes) were separated from GFP-negative cells (enriched in osteoblasts) by immediately subjecting the cell suspension to fluorescenceactivated sorting using an Aria flow cytometer (BD Biosciences, San Jose, CA, USA) at the Massachusetts General Hospital Flow Cytometry Core Facility.

\section{Bone mineral density DEXA}

Mouse BMD was measured by DEXA using a Lunar PIXImus II densitometer (GE Medical System Luna, Madison, WI, USA). In brief, mice were killed; right femurs and vertebral bodies were fixed overnight in 10\% buffered formalin and then preserved in $70 \%$ ethanol. The excised right femurs and vertebral bodies (region L4-L5) were used to determine bone mineral content $(\mathrm{g})$ and BMD $\left(\mathrm{g} / \mathrm{cm}^{2}\right)$.

\section{Micro-computed tomography $(\mu C T)$ analysis}

Assessment of bone morphology and microarchitecture was performed using a desktop high-resolution $\mu \mathrm{CT}(\mu \mathrm{CT} 40$, Scanco Medical, Brüttisellen, Switzerland), as described previously (Bouxsein et al. 2010). In brief, the distal femoral metaphysis and L5 vertebral body were scanned using an X-ray energy of $70 \mathrm{keV}$, integration time of $200 \mathrm{~ms}$, and a $12 \mu \mathrm{m}$ isotropic voxel size. For the cancellous bone region, we assessed bone volume fraction (BV/TV, \%), trabecular 
thickness (Tb.Th, $\mu \mathrm{m})$, trabecular separation (Tb.Sp, $\mu \mathrm{m}$ ), trabecular number (Tb.N, $1 / \mathrm{mm}$ ), connectivity density (Conn.D, $1 / \mathrm{mm}^{3}$ ), and structure model index (SMI).

\section{Statistical analysis}

All data are presented as mean \pm s.D. The statistical significance of differences between groups was determined by Student's $t$-test. $P$ values $<0.05$ were accepted as significant.

\section{Results}

Generation and characterization of $10 \mathrm{~kb}$-Dmp1-Cre-ERT2 transgenic mice

$10 \mathrm{~kb}-$ Dmp1-Cre-ERT2 animals were generated as described in Materials and Methods. To test the efficiency and specificity of the lines generated, the $10 \mathrm{~kb}-\mathrm{Dmp} 1$-CreERT2 animals were intercrossed with the homozygous ROSA26R reporter mice (Soriano 1999). ROSA26R mice have a floxed stop-cassette upstream of the $L a c Z$ gene. In the presence of Cre-recombinase activity, the stop cassette is excised, LacZ is expressed, and $\beta$-galactosidase ( $\beta$-gal) activity can be detected using the 5-bromo-4-chloro-3-indolyl-Dgalactopyranoside (X-gal) staining procedure. Three-day-old $10 \mathrm{~kb}-D m p 1-C r e-E R T 2 / R O S A 26 \mathrm{R}$ mice were exposed to i.p. injections of tamoxifen $(50-60 \mu \mathrm{g} / \mathrm{g})$ at days 3,5 , and 7 , and then maintained on a weekly injection of $5-10 \mu \mathrm{g} / \mathrm{g}$ of tamoxifen for an additional 2 weeks. After X-gal staining, calvarial bones and hindlimbs were embedded in paraffin and stained with eosin. In some experiments, kidneys were also evaluated for $\mathrm{X}$-gal staining. As shown in Fig. 2A-C for calvaria (DP1-cre positive: A top panel and B at $40 \times$ and DMP1-Cre negative: A bottom panel and $\mathrm{C}$ at $40 \times)$ and Fig. 2D-F for long bone (femur of DMP1-Cre positive: D top panel and $\mathrm{E}$ at $40 \times$ and DMP1-Cre negative: $\mathrm{D}$ bottom panel and $F$ at $40 \times$ ) for one founder, most of the osteocytes were positive for the $\mathrm{X}$-gal staining (Fig. 2A and D, top panels and $\mathrm{B}$ and $\mathrm{E}$ ), while no staining was present in Dmp 1-Crenegative controls (Fig. 2A and D, bottom panels and C and F), in kidneys, bone marrow, or skeletal muscle of DMP1-Cre positive (Supplemental Figure 2A, C, and D, see section on supplementary data given at the end of this article), or in Dmp1-Cre-positive animals not treated with tamoxifen (data not shown). Under this regimen, we calculated that $77 \pm 9 \%$
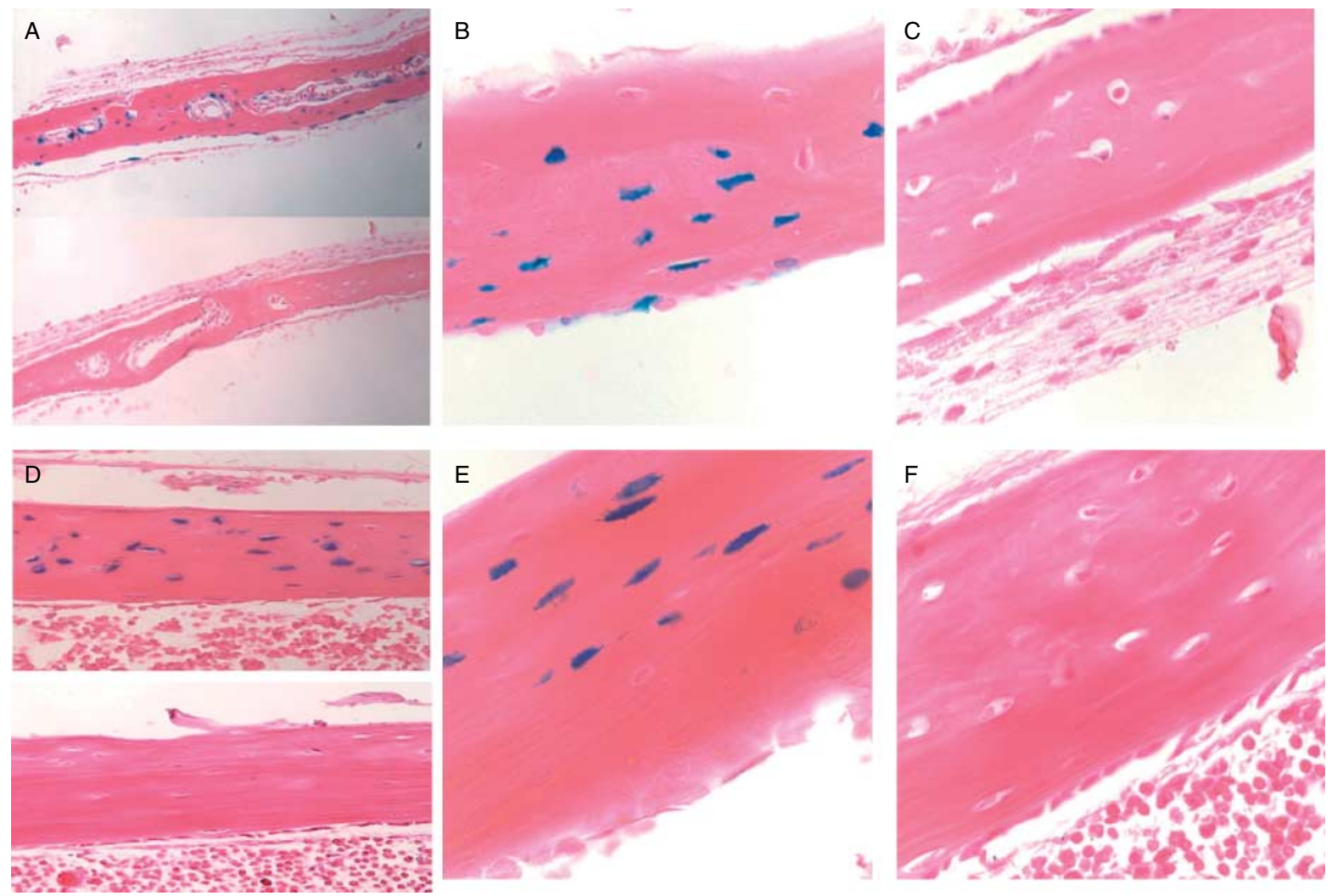

Figure 2 Characterization of DMP1-Cre-ET2 mice. X-gal staining of 5-week-old calvarial (A-C) and long bones (femur) (D-F) from Rosa26:10 kb-DMP1-Cre-positive (A top panel and B: calvaria; D top panel and E: femur) and Cre-negative (A bottom panel and C: calvaria; D bottom panel and F; femur) mice. Animals were injected with tamoxifen at days 3, 5, 7, 14, and 21 postnatally and killed at 23 days ( 2 days after last tamoxifen injection). Panels A and D: $20 \times$ magnification; panels B, C, E, and F: $40 \times$ magnification. 
of osteocytes stained blue for X-gal activity $(81 \cdot 3 \pm 3 \%$ in calvaria; $72 \cdot 6 \pm 6 \%$ in tibiae, and $78 \cdot 5 \pm 1 \cdot 1 \%$ in femurs), indicating excision of the flox-stop codon in the lac $Z$ promoter region in these cells. In addition, to further assess the specificity of the promoter, we calculated the percentage of X-gal-positive endosteal and periosteal osteoblasts. Under the regimen described above, $8 \cdot 6 \pm 6 \cdot 8 \%$ of calvaria osteoblasts and $1 \cdot 1 \pm 1 \%$ of femoral osteoblasts were positive for X-gal staining, indicating that only a minority of mature osteoblasts express the $10 \mathrm{~kb}$ Dmp 1-promoter. Initial analysis showed that two of the six lines demonstrated highly penetrant excision of the ROSA26R stop cassette, and we focused our experiments on these two lines.

In another set of experiments, 3- to 4-week-old mice were injected with $5-10 \mu \mathrm{g} / \mathrm{g}$ of tamoxifen three times a week for 2-4 weeks before analyzing PPR expression by real-time qPCR. The efficiency of PPR ablation, as assessed by qPCR in mRNA derived from collagenase-digested long bones, with this tamoxifen regimen was again around $60-70 \%$, and was comparable to the one described above (Fig. 3A), indicating that the receptor can be successfully ablated in adult mice.

\section{DMP1-Cre-ERT2 model effectively and specifically decreases} PPR expression in osteocytes

$10 \mathrm{~kb}-$ Dmp 1-Cre-ERT2 mice were crossed with homozygous PPR-floxed mice, as described in Materials and Methods, to obtain double heterozygotes that were in turn mated with $\mathrm{PPR}^{\mathrm{f} / \mathrm{fl}}$ to obtain $10 \mathrm{~kb}-D m p$ 1-Cre-ERT2:PPR ${ }^{\mathrm{fl} / \mathrm{fl}}$ or 'Ocy-PPR ${ }^{\mathrm{cKO}}$, mice and littermate controls.

$10 \mathrm{~kb}-D m p 1-C r e-E R T 2: \mathrm{PPR}^{\mathrm{fl} /+}$ females were time mated with $\mathrm{PPR}^{\mathrm{f} / \mathrm{fl}}$ males and injected i.p. with $2 \mathrm{mg}$ of tamoxifen at $17 \cdot 5$ days post-coitus. Pups were killed 1 day after birth, genotyped, and long bones were excised and analyzed histologically. As anticipated, given the short interval between tamoxifen induction and killing, we did not observe any macroscopic phenotype in the Ocy-PPR ${ }^{\mathrm{cKO}}$ pups, nor any overt osteocyte phenotype in the calvarial and long bones of these mice compared to littermate controls. Immunohistochemical analysis using anti-sclerostin antibody showed no differences in expression between Ocy-PPR ${ }^{\text {cKO }}$ and littermate calvaria and long bones after 3 days of exposure to tamoxifen.

To ascertain the successful deletion of PPR from osteocytes in response to the tamoxifen regimen, we first carried out qPCR analysis for PPR expression. Mice, both Ocy-PPR ${ }^{\text {cKO }}$ and littermate controls, were injected with tamoxifen at days 3, 5, and 7 and then weekly, as described above. We performed real-time $\mathrm{qPCR}$ for the PPR using primers specific for the floxed E1 region. As shown in Fig. 3A, Ocy-PPR ${ }^{\mathrm{cKO}}$ femurs had a $64 \%$ reduction in PPR expression compared to littermate controls (results are expressed as percentage of control and are normalized by GAPDH). To further evaluate PPR ablation in a pure osteocytic population, we generated Ocy-PPR ${ }^{\mathrm{cKO}}$ and control mice that express
GFP under the $8 \mathrm{~kb}$-DMP1 promoter by mating the $\mathrm{PPR}^{\mathrm{fl} / \mathrm{fl}}$ mice with the $8 \mathrm{~kb}$-DMP1-GFP mice. Newborn pups were genotyped and then injected with $50 \mu \mathrm{g} / \mathrm{g}$ of tamoxifen at days 2 and 4 postnatally. Primary calvarial cells were then isolated by eight sequential collagenase and EDTA digestions, and cells derived from fractions 3 to 8 were sorted, as described in Materials and Methods. As shown in Fig. 3B, PPR expression was reduced by $80 \%$ in GFP-positive cells from Ocy-PPR ${ }^{\mathrm{cKO}}$ animals compared to littermate controls (control $100 \pm 8 \cdot 8 \%$, Ocy-PPR ${ }^{\mathrm{cKO}} 23 \cdot 1 \pm 0 \cdot 27 \%$, controlGFP neg $48 \cdot 1 \pm 17 \cdot 5 \%$, and Ocy-PPR ${ }^{\text {cKO }}$-GFP neg $52 \cdot 7 \pm 8 \cdot 8 \%$, results are expressed as percentage of control and are normalized for GAPDH expression). There was no significant difference in PPR expression in GFP-negative cells
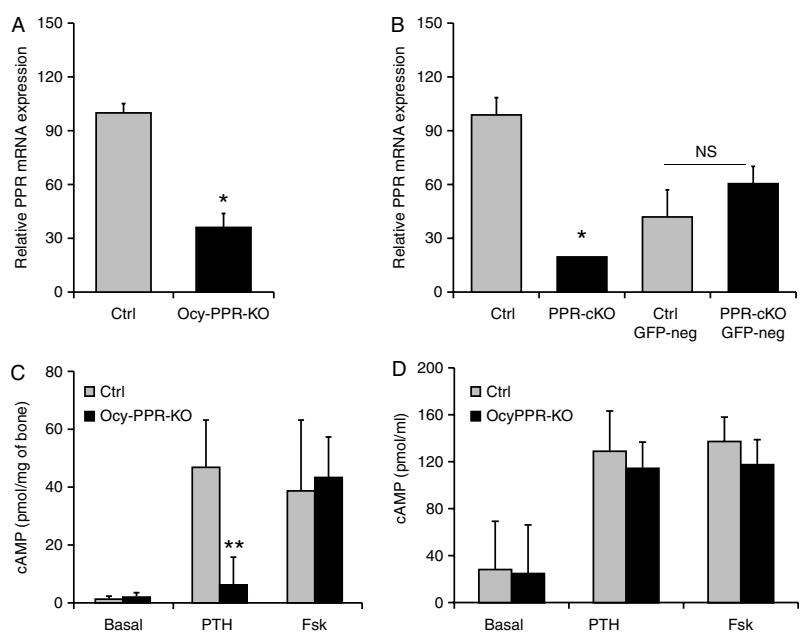

Figure 3 PPR ablation in osteocytes. Real-time qPCR from (A) RNA extracted from femurs of 5-week-old littermate controls (Ctrl, $n=3$ ) and Ocy-PPR ${ }^{\mathrm{CKO}}(n=3)$ mice. Data are expressed as relative mRNA using the $-\Delta \Delta C_{\mathrm{T}}$ formula, normalized by GAPDH and expressed as percentage of controls. PPR expression in the Ocy-PPR ${ }^{\text {cKO }}$ is decreased to $36 \cdot 1 \pm 7 \cdot 7 \%$ of controls. Data are expressed as mean \pm s.D. of triplicates. ${ }^{*} P<0 \cdot 05$. Representative experiment. (B) Real-time qPCR of RNA extracted from sorted GFP-positive and GFP-negative calvarial cells derived from Ocy-PPR ${ }^{\text {cKO }}$ (PPR-cKO) and control littermates (Ctrl). Data are expressed as percentage of controls and are corrected for GAPDH. PPR expression in GFPpositive Ocy-PPR ${ }^{\mathrm{CKO}}$ osteocytes (PPR-KO) is decreased by $80 \%$ compared to littermate control GFP-positive osteocytes (Ctrl) (two left-most bars). PPR expression in GFP-negative cells (osteoblasts) from controls and Ocy-PPR ${ }^{\mathrm{CKO}}$ animals is not significantly different (two right-most bars). Data are expressed as mean \pm s.D. of triplicates. ${ }^{*} P<0 \cdot 05$. Representative experiment. (C) cAMP accumulation in bone marrow-deprived, collagenase-digested tibial explants. Right tibiae of 5-week-old Ocy-PPR ${ }^{\mathrm{cKO}}(n=3$, black bars) and control littermates ( $n=4$, gray bars) were assayed for their in vitro responsiveness to $100 \mathrm{nM} \mathrm{hPTH}(1-34)$ or $10 \mu \mathrm{M}$ forskolin (Fsk). Data are expressed as pmol of cAMP/mg of bone. Data are expressed as mean \pm s.D. of triplicates. ${ }^{* *} P<0 \cdot 002$ Ocy-PPR ${ }^{\mathrm{CKO}}$ versus WT. (D) CAMP accumulation in primary calvarial cells. Primary calvarial cells from 4- to 5-day-old pups were assayed for their in vitro responsiveness to $100 \mathrm{nM} \mathrm{hPTH}(1-34)$ or $10 \mu \mathrm{M}$ forskolin (Fsk). Data are expressed as pmol cAMP/well. Data are expressed as mean \pm s.D. of triplicates. 
compared to Ocy-PPR ${ }^{\mathrm{cKO}}$ and control animals (osteoblasts). These results demonstrate that the PTH receptor ablation is specific for osteocytes and that it can be induced upon tamoxifen administration. Interestingly, receptor expression in control GFP-positive cells (osteocytes) is twofold that of GFP-negative cells (osteoblasts), suggesting higher receptor expression in osteocytes than osteoblasts.

In addition, allele-specific DNA recombination for the PPR locus was evaluated by PCR using primer spanning the floxed E1 region. As shown in Fig. 1C, the DNA recombination (lower band) was observed only in the skeletal tissues such as long bones (bone marrow-depleted femurs) and calvaria, whereas no recombination was detected in kidney, spleen, muscle, and liver, indicating that the PPR ablation was specific for osteocytes.

\section{Functional consequences of deletion of the PPR gene in osteocytes}

To assess functional ablation of the PPR in osteocytes, we measured PTH-induced cAMP accumulation in osteoblast/marrow cell-depleted bone explants, enriched in osteocytes, from Ocy-PPR ${ }^{\mathrm{cKO}}$ and littermate controls. Tibiae were isolated from 4- to 5-week-old Ocy-PPR ${ }^{\mathrm{cKO}}$ and control littermates injected with tamoxifen $(50-60 \mu \mathrm{g} / \mathrm{g})$ at days 3,5 , and 7 postnatally and then weekly with $5-10 \mu \mathrm{g} / \mathrm{g}$, as described for the ROSA26R experiments. As shown in Fig. 3C, there was a statistically significant reduction $(86 \cdot 8 \%$ reduction) of cAMP accumulation in response to $\mathrm{PTH}$ in Ocy-PPR ${ }^{\text {cKO }}$ osteocyte-enriched bone fragments, compared to littermate controls $\left(\mathrm{Ocy}-\mathrm{PPR}{ }^{\mathrm{cKO}}=6 \cdot 16 \pm 9 \cdot 6 \mathrm{picomol} / \mathrm{mg}\right.$ bone versus control $=46.9 \pm 16.2 \mathrm{picomol} / \mathrm{mg}$ bone; $P<0 \cdot 05)$. As a positive control, no difference was detected in the response to forskolin $\left(\mathrm{Ocy}-\mathrm{PPR}^{\mathrm{cKO}}=43 \cdot 4\right.$ $\pm 13.8 \mathrm{picomol} / \mathrm{mg}$ bone versus littermate controls $=36.7$ $\pm 23.9 \mathrm{picomol} / \mathrm{mg}$ bone) indicating an intact adenylyl cyclase machinery in these osteocyte-enriched bone fragments. To assess that PPR ablation was confined to osteocytes and not to osteoblasts, we performed cAMP accumulation in response to $\mathrm{PTH}$ in primary calvarial cells (predominantly composed of osteoblasts) isolated from 4- to 5-day-old
A
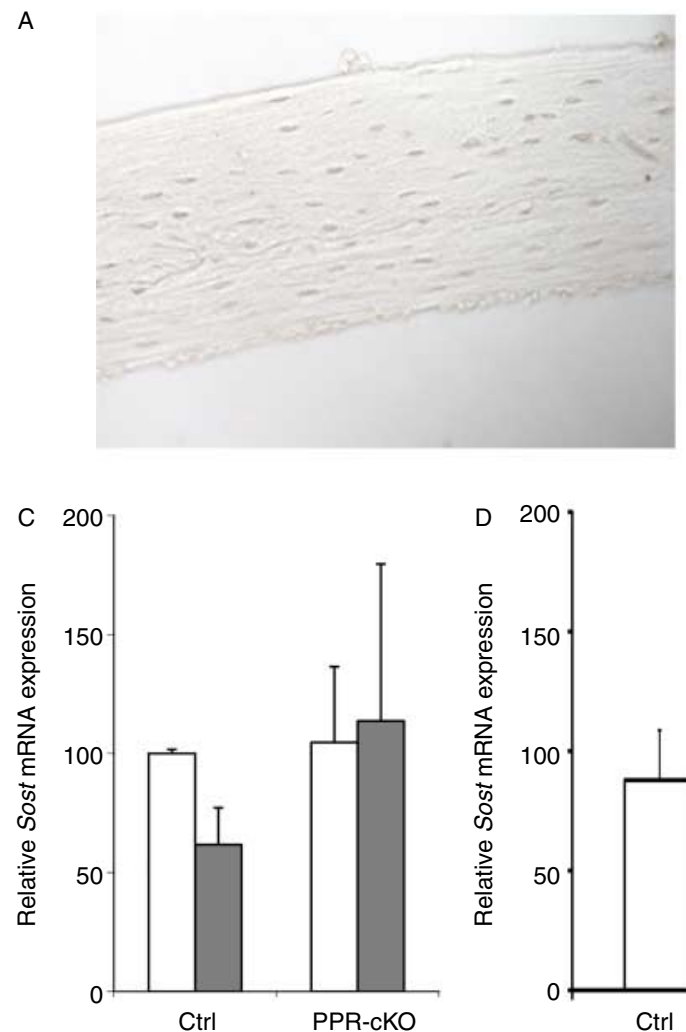

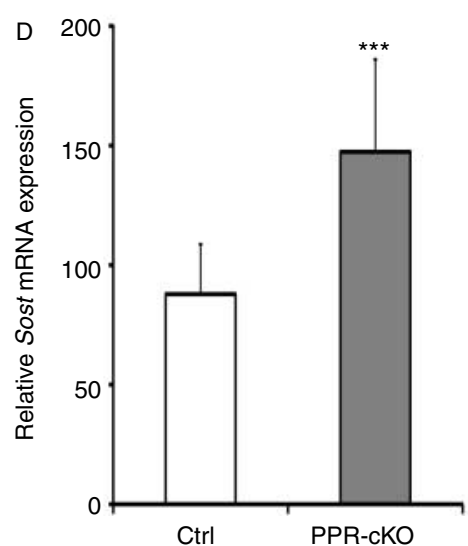

Figure 4 Sost and Sclerostin expression in Ocy-PPR ${ }^{\mathrm{CKO}}$. Immunohistochemistry for sclerostin was performed on sections of bone isolated from Ocy-PPR ${ }^{\mathrm{cKO}}(\mathrm{A})$ and littermate controls $(\mathrm{B})$ pre-treated with $0.5 \mathrm{mg}$ tamoxifen three times a week for 4 weeks prior to acute s.c. injection with $300 \mu \mathrm{g} / \mathrm{kg}$ of PTH (1-34). Mice were killed $1 \mathrm{~h}$ after the hormone injection. (C) Real-time qPCR of SOST mRNA from femurs of control littermates (Ctrl) and Ocy-PPR ${ }^{\mathrm{cKO}}$ (PPR-cKO) acutely injected with $300 \mu \mathrm{g} / \mathrm{kg}$ of PTH (1-34) (gray bars) or vehicle alone (open bars). Data are expressed as percentage of vehicle-treated mice and normalized for GAPDH. (D) Real-time qPCR of Sost mRNA from femurs of 4- to 6-week-old Ocy-PPR ${ }^{\mathrm{cKO}}$ (PPR-cKO, $\left.n=9\right)$ and control littermates (Ctrl, $\left.n=8\right)$. ${ }^{* * *} P<0 \cdot 005$. (E) Real-time qPCR of Axin-2 mRNA from femurs of 4- to 6-week-old Ocy-PPR ${ }^{\mathrm{CKO}}(\mathrm{PPR}-\mathrm{cKO}, n=7)$ and control littermates $(\mathrm{WT}, n=7) .{ }^{*} P<0 \cdot 05$. Full colour version of this figure available via http://dx.doi.org/10.1530/JOE-10-0308. 
Ocy-PPR ${ }^{\mathrm{cKO}}$ and littermate controls. As shown in Fig. 3D, cAMP accumulation in calvarial osteoblasts from $\mathrm{Ocy}-\mathrm{PPR}^{\mathrm{cKO}}$ was indistinguishable from littermate controls, indicating that PPR ablation was specific for osteocytes.

Moreover, primary calvaria cells isolated from 4- to 5-dayold Ocy-PPR ${ }^{\text {cKO }}$ and littermate controls were treated with $100 \mathrm{nM} \mathrm{hPTH} \mathrm{(1-34)} \mathrm{for} 4 \mathrm{~h}$, and RANKL expression was assessed by qPCR. As expected, RANKL was significantly up-regulated in both Ocy-PPR ${ }^{\mathrm{cKO}}$ and littermate controls $(7 \cdot 6 \pm 2 \cdot 5$ - and $18 \cdot 5 \pm 1 \cdot 8$-fold respectively) indicating that osteoblasts in Ocy-PPR ${ }^{\mathrm{cKO}}$ do have intact $\mathrm{PTH}$ responsiveness.

To further assess the phenotype of mice lacking PPR in osteocytes, we proceeded to analyze adult mice. Four- to sixweek-old mice were injected with tamoxifen $(20-30 \mu \mathrm{g} / \mathrm{g})$ three times a week for 4 weeks. At the end of the 4 weeks, mice were acutely challenged with a single s.c. injection of human PTH $(1-34 ; 300 \mu \mathrm{g} / \mathrm{kg})$ and killed after $1 \mathrm{~h}$. As shown in Fig. 4A, sclerostin expression (assessed immunohistochemically) was markedly reduced in the tibiae of littermate control animals following PTH administration, but was readily detectable in tibiae of $\mathrm{Ocy}-\mathrm{PPR}^{\mathrm{cKO}}$ animals (Fig. 4B), demonstrating no PTH-induced sclerostin inhibition in Ocy-PPR ${ }^{\mathrm{cKO}}$ mice. We also analyzed Sost mRNA expression by real-time PCR, with Ocy-PPR ${ }^{\mathrm{cKO}}$ mice showing no acute reduction of Sost expression after PTH injection, whereas controls showed more than a $40 \%$ acute down-regulation of Sost mRNA expression (Fig. 4C). Moreover, Ocy-PPR ${ }^{\mathrm{cKO}}$ also displayed a significant overall increase in Sost expression of more than $54 \%$, as detected by real-time $\mathrm{qPCR}$ (control $=90 \pm 20$ versus Ocy-PPR ${ }^{\mathrm{cKO}}$ $147 \pm 33 \%, n=9 ; P<0 \cdot 01$; Fig. $4 \mathrm{D})$ as well as a suppression of Wnt-signaling pathways as demonstrated by a significant reduction of Axin-2 mRNA (control $=109 \pm 47$ versus Ocy-PPR $^{\text {cKO }} 65 \pm 25 \%, n=7 ; P<0 \cdot 05$; Fig. 4E).

We then analyzed the bone phenotype of Ocy-PPR ${ }^{\mathrm{cKO}}$ and littermate controls. Hematoxylin and eosin staining of decalcified tibiae demonstrated a reduction of trabecular bone and a delay in the secondary ossification center. Furthermore, Von Kossa staining of plastic (Fig. 5A and B) sections confirmed a reduction of the trabecular bone. We measured BMD in isolated femurs and vertebral bodies (L4-L5) by DEXA (Piximus) in both females and males. In Ocy-PPR ${ }^{\text {cKO }}$ females, there was a significant reduction of both vertebral and femoral BMD (Fig. 5C and D). Males also tended to have a lower BMD compared to littermate controls, but this was not significantly different.

To investigate whether the low BMD in Ocy-PPR ${ }^{\mathrm{cKO}}$ mice was due to a reduction in osteoblast activity, an increase in osteoclast activity, or a combination of both, we measured markers of bone resorption and bone formation in control and Ocy-PPR ${ }^{\mathrm{cKO}}$ mice, as shown in Table 1. Serum levels of collagen type 1 fragment were indistinguishable between Ocy-PPR ${ }^{\mathrm{cKO}}$ and control littermates (PINP: controls, $n=17$, $70 \cdot 3 \pm 51 \cdot 2 \mathrm{ng} / \mathrm{ml} ; \quad$ Ocy-PPR ${ }^{\mathrm{cKO}}, n=14,74 \cdot 9 \pm 55 \cdot 2 \mathrm{ng} /$ $\mathrm{ml})$, whereas CTX was slightly elevated in $\mathrm{KO}$ mice compared to controls (controls, $n=9,9 \cdot 07 \pm 5.03 \mathrm{ng} / \mathrm{ml}$; Ocy-PPR $\left.{ }^{\mathrm{cKO}}, n=11,13 \cdot 8 \pm 6 \cdot 7 \mathrm{ng} / \mathrm{ml}\right)$ although they were not statistically different. Finally, TRAP5b was not significantly different between control and Ocy-PPR ${ }^{\mathrm{cKO}}$ mice (TRAP5b: controls, $n=16,1.51 \pm 0.78 \mathrm{U} / 1$; Ocy-PPR ${ }^{\mathrm{cKO}}$, $n=12,1 \cdot 08 \pm 0 \cdot 44 \mathrm{U} / 1)$, suggesting that rates of bone modeling and remodeling are relatively normal in these mice. To further evaluate the bone architecture of
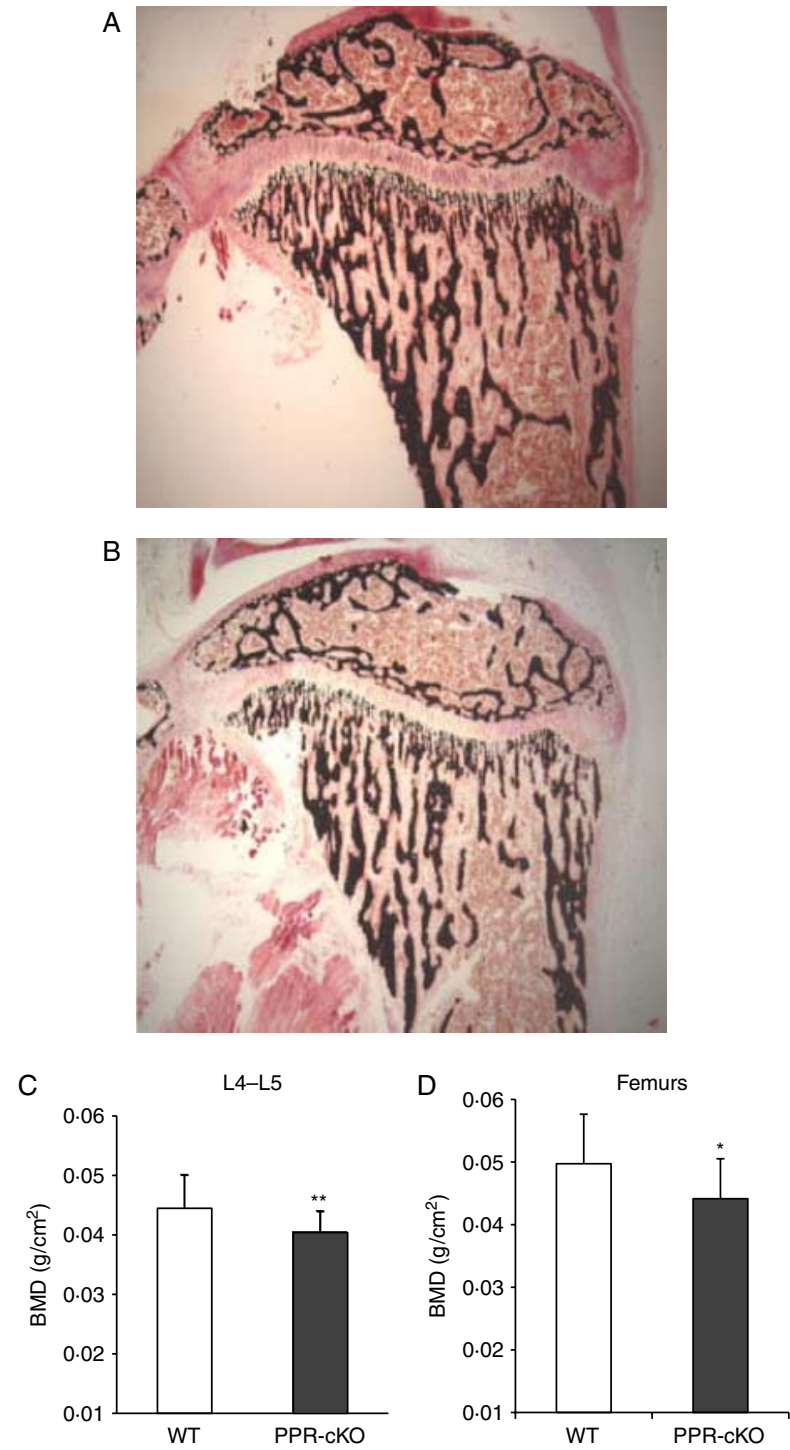

Figure 5 Osteopenia in Ocy-PPR ${ }^{\mathrm{cKO}}$. Von Kossa (A and B) staining of 3- to 4-week-old tibia of controls (A) and Ocy-PPR ${ }^{\mathrm{CKO}}$ (B) mice. Mice were injected with tamoxifen as described in Fig. 2. Ocy$\mathrm{PPR}^{\mathrm{CKO}}$ animals demonstrated a decrease in trabecular bone and a delay in secondary ossification center. (C and D) Low bone mineral density in Ocy-PPR ${ }^{\mathrm{CKO}}$. BMD of vertebral bodies (L4-L5) (E) and femurs (F) of Ocy-PPR ${ }^{\text {cKO }}(n=11)$ and control $(n=13)$ females. BMD was measured by DXA on isolated bones. Data are expressed as mean \pm s.D. ${ }^{*} P<0 \cdot 1,{ }^{* *} P<0 \cdot 05$. Full colour version of this figure available via http://dx.doi.org/10.1530/JOE-10-0308. 
Table 1 Serum markers of bone formation and bone resorption in controls and Ocy-PPR ${ }^{\mathrm{cKO}}$ animals. Data are expressed as average \pm S.D.

\begin{tabular}{|c|c|c|}
\hline & Controls & Ocy-PPR ${ }^{\text {cKO }}$ \\
\hline PINP (ng/ml) & $\begin{array}{l}70 \cdot 3 \pm 51 \cdot 2 \\
n=17\end{array}$ & $\begin{array}{l}74 \cdot 9 \pm 55 \cdot 2 \\
n=14\end{array}$ \\
\hline CTX (ng/ml) & $\begin{array}{l}9 \cdot 07 \pm 5 \cdot 03 \\
n=9\end{array}$ & $\begin{array}{l}13 \cdot 8 \pm 6 \cdot 7 \\
n=11\end{array}$ \\
\hline TRAP5B (U/I) & $\begin{array}{l}1 \cdot 51 \pm 0 \cdot 78 \\
n=16\end{array}$ & $\begin{array}{l}1 \cdot 08 \pm 0 \cdot 44 \\
n=12\end{array}$ \\
\hline $\begin{array}{l}\text { Low-calcium diet } \\
\text { Ionized Ca }(\mathrm{mmol} / \mathrm{l}) \\
\text { Total Ca }(\mathrm{mg} / \mathrm{dl})\end{array}$ & $\begin{array}{l}1 \cdot 24 \pm 0 \cdot 03 \\
8 \cdot 45 \pm 0 \cdot 295 \\
n=11\end{array}$ & $\begin{array}{l}1 \cdot 07 \pm 0 \cdot 08^{*} \\
7 \cdot 93 \pm 0 \cdot 317^{\dagger} \\
n=12\end{array}$ \\
\hline
\end{tabular}

${ }^{*} P<0 \cdot 05,{ }^{+} P<0 \cdot 0001$.

Ocy-PPR ${ }^{\mathrm{cKO}}$ mice, we performed $\mu \mathrm{CT}$ analysis of trabecular bone both in males and in females. As shown in Table 2, Ocy-PPR ${ }^{\mathrm{cKO}}$ tended to have lower trabecular bone compared to controls (reduced connectivity density, SMI, and trabeculae number), although this was not statistically significant indicating that ablation of PPR in osteocytes induces mild skeletal abnormalities, as assessed by $\mu \mathrm{CT}$.

Finally, to further analyze PPR KO in osteocytes, we subjected 6-week-old mice to 2 weeks of a low-calcium diet $(0 \cdot 02 \%$ calcium $)$ to induce secondary hyperparathyroidism. Mice were pre-treated with tamoxifen $(20-30 \mu \mathrm{g} / \mathrm{g}$ three times a week) 1 week before starting the diet and during the 2 weeks of the diet. Ionized calcium was measured at the beginning of the study (before starting tamoxifen injections) and was not significantly different between groups. At the end of the 3 weeks, mice were killed, and blood and skeletal specimens were collected and analyzed as described above. Plasma PTH levels in these mice were elevated $(190 \cdot 7 \pm 82$ and $294 \cdot 8 \pm 124 \mathrm{pg} / \mathrm{ml}$ for control and Ocy-PPR ${ }^{\mathrm{cKO}}$ respectively), confirming that secondary hyperparathyroidism had been achieved. Interestingly, Ocy-PPR ${ }^{\mathrm{cKO}}$ animals displayed significantly lower ionized and total calcium levels compared to littermate controls (which included DMP1-Cre:PPR ${ }^{\mathrm{fl} / \mathrm{fl}}$ not treated with tamoxifen and tamoxifen-treated DMP1-Cre:PPR ${ }^{\mathrm{fl} /+}$ and $\mathrm{PPR}^{\mathrm{fl} / \mathrm{fl}}$; Fig. $6 \mathrm{~A}$ and $\mathrm{B}$ and Table 1). Similar results were also obtained in a separate set of experiments using younger mice treated with tamoxifen from day 3 postnatally to ablate PPRs at an earlier time when data were not shown. In these mice, tamoxifen was administered at days $3,5,7,14$, and 21 postnatally, and mice were fed a low-calcium diet at day 21 for an additional 2 weeks. In addition, PPR expression in the kidneys of these animals was evaluated to ascertain that the receptor was fully expressed in this organ. We did not observe any difference in PPR mRNA levels between Ocy-PPR ${ }^{\mathrm{cKO}}$ and littermate controls, indicating that the lower serum calcium level was not likely due to altered renal responsiveness to circulating PTH.

\section{Discussion}

Osteocytes are believed to play a key role in skeletal mechanosensing whereby they modulate bone modeling and remodeling in response to changes in shear or strain forces. Moreover, recent studies (O'Brien et al. 2006) demonstrated that mice in which the constitutively active PPR is expressed in osteocytes display a dramatic increase in trabecular bone, indicating an important role of PTH and the PPR in osteocytes.

To investigate the role of PTH and related molecules in osteocytes in vivo, we have generated mice in which the receptor is selectively and temporary ablated in these cells. We used the $9.6 \mathrm{~kb}$ of the DMP1-promoter to drive a tamoxifen-inducible Cre-recombinase in mice in which exon-1 of the PPR is flanked by lox-P sites. Ocy-PPR ${ }^{\text {cKO }}$ mice were born with the expected Mendelian ratio, were viable, and were indistinguishable from littermate controls, indicating that the Cre-recombinase was not expressed in the absence of tamoxifen induction. The $10 \mathrm{~kb}-\mathrm{DMP} 1-\mathrm{Cre}-$ ERT2 recombinase was exclusively and specifically expressed in osteocytes and in rare bone lining cells $(<8 \%$ of total endosteal osteoblasts), as demonstrated by ROSA26 experiments. The promoter was readily inducible, and the efficiency of Cre-recombinase excision was around $70-80 \%$. The transgene was heritable as assessed by Southern blot analysis of F2 generation of the original founders.

Initial characterization of the Ocy-PPR ${ }^{\mathrm{cKO}}$ mice revealed a slight growth retardation (data not shown) that was associated with a mild osteopenic phenotype, as assessed by histological analysis of long bones and by DEXA measurement. Interestingly, vertebral and femoral BMD (as assessed by

Table 2 Trabecular bone architecture of vertebral body (L5) and femoral distal end was analyzed by $\mu \mathrm{CT}$ at $8-12$ weeks of age in female and male mice. Data are expressed as average \pm s.D.

\begin{tabular}{|c|c|c|c|}
\hline & $\begin{array}{l}\text { Controls } \\
\quad(n=11)\end{array}$ & $\begin{array}{c}\text { Ocy-PPR }^{\text {cKO }} \\
(n=11)\end{array}$ & $\boldsymbol{P}$ \\
\hline \multicolumn{4}{|l|}{ Females (L5) } \\
\hline $\mathrm{BV} / \mathrm{TV} \%$ & $30 \cdot 76 \pm 5 \cdot 9$ & $28 \cdot 7 \pm 7 \cdot 5$ & $0 \cdot 497$ \\
\hline Conn.D $\left(1 / \mathrm{mm}^{3}\right)$ & $304 \cdot 8 \pm 70 \cdot 2$ & $295 \cdot 2 \pm 85 \cdot 8$ & $0 \cdot 779$ \\
\hline SMI & $0 \cdot 046 \pm 0 \cdot 76$ & $0 \cdot 38 \pm 0 \cdot 93$ & $0 \cdot 358$ \\
\hline Tb.N (1/mm) & $4.99 \pm 0 \cdot 61$ & $4 \cdot 99 \pm 0 \cdot 74$ & $0 \cdot 862$ \\
\hline Tb.Th $(\mu \mathrm{m})$ & $0 \cdot 052 \pm 0.004$ & $0 \cdot 051 \pm 0 \cdot 006$ & $0 \cdot 893$ \\
\hline \multirow[t]{2}{*}{ Tb. Sp $(\mu \mathrm{m})$} & $0 \cdot 207 \pm 0 \cdot 023$ & $0 \cdot 209 \pm 0 \cdot 036$ & $0 \cdot 919$ \\
\hline & $\begin{array}{l}\text { Controls } \\
\quad(n=10)\end{array}$ & $\begin{array}{c}\text { Ocy-PPR }^{\text {cKO }} \\
(n=6)\end{array}$ & $\boldsymbol{P}$ \\
\hline \multicolumn{4}{|c|}{ Males (distal femur) } \\
\hline $\mathrm{BV} / \mathrm{TV} \%$ & $28 \cdot 53 \pm 14 \cdot 5$ & $30 \cdot 6 \pm 12 \cdot 4$ & $0 \cdot 755$ \\
\hline Conn.D $\left(1 / \mathrm{mm}^{3}\right)$ & $236 \pm 144 \cdot 8$ & $158 \cdot 5 \pm 39 \cdot 4$ & $0 \cdot 191$ \\
\hline SMI & $1 \cdot 21 \pm 1 \cdot 32$ & $0.79 \pm 0.93$ & 0.691 \\
\hline Tb.N (1/mm) & $6 \cdot 07 \pm 1 \cdot 81$ & $5 \cdot 36 \pm 1 \cdot 07$ & $0 \cdot 373$ \\
\hline Tb.Th $(\mathrm{mm})$ & $0 \cdot 061 \pm 0 \cdot 01$ & $0.074 \pm 0.01$ & 0.067 \\
\hline Tb. Sp (mm) & $0 \cdot 167 \pm 0 \cdot 049$ & $0 \cdot 190 \pm 0.05$ & $0 \cdot 372$ \\
\hline
\end{tabular}



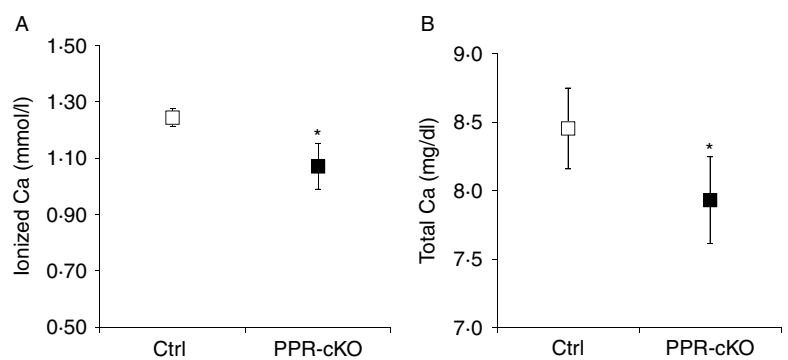

Figure 6 Plasma-ionized and total calcium levels in Ocy-PPR ${ }^{\mathrm{cKO}}$ (PPR-KO) and littermate controls (Ctrl) mice. Six-week-old mice were treated with $0.5 \mathrm{mg}$ tamoxifen three times a week for 3 weeks and challenged with a low-calcium diet for 2 weeks. Data are expressed as mean \pm s.D. Blood was collected at the end of the 3 weeks and analyzed for calcium content. Data are expressed as mean \pm s.D. Ocy-PPR ${ }^{\mathrm{cKO}}, n=5$; controls, $n=3 .{ }^{*} P<0 \cdot 05$.

(A) lonized calcium; (B) total calcium.

Piximus) was significantly lower than littermate controls only in females, suggesting a potential effect of gender on PTH action on osteocytes. Moreover, when bone microarchitecture was analyzed by $\mu \mathrm{CT}$, there was no significant difference between the Ocy-PPR ${ }^{\mathrm{cKO}}$ and littermate controls (although the KO mice displayed lower Conn.D, SMI, and Tb.N), suggesting that the bone abnormalities in $\mathrm{Ocy}-\mathrm{PPR}^{\mathrm{cKO}}$ are mild. One possible explanation for the discrepancy between DEXA and $\mu \mathrm{CT}$ is the different area of bone that is routinely analyzed by these two techniques.

In Ocy-PPR ${ }^{\mathrm{cKO}}$ mice, Sost and sclerostin expression was significantly higher than in littermate controls, indicating that the osteopenia might be a consequence of suppression of the wnt $-\beta$-catenin signaling pathway in osteocytes, as demonstrated by a significant suppression of Axin-2 mRNA expression (Fig. 4D) in Ocy-PPR ${ }^{\mathrm{cKO}}$. Sclerostin, the secreted protein product of the SOST gene, is expressed exclusively by osteocytes and has emerged as a potent indirect negative regulator of bone osteoblastogenesis (Winkler et al. 2003, van Bezooijen et al. 2004, 2005). Transgenic mice overexpressing Sost show low bone mass (Winkler et al. 2003), whereas Sostnull animals have high bone mass (HBM). Sclerostin acts by binding the low-density lipoprotein receptor 5 and 6 (LRP5 and 6) and inhibits wnt- $\beta$-catenin signaling pathway (Ai et al. 2005). Also, the HBM mutation of Lrp5, G171V, binds less efficiently to sclerostin. Inhibition of wnt- $\beta$-catenin in osteocytes, in turn, somehow suppresses osteoblast proliferation and function. Several studies have proven that the wnt$\beta$-catenin pathway is critical for proper bone metabolism, as again revealed by loss-of-function or gain-of-function mutations of LRP5 that cause respectively osteoporosispseudoglioma syndrome or HBM syndrome, in humans and rodents (Gong et al. 2001). Our data suggest that PTH exerts its anabolic effect on bone, at least in part, by suppressing sclerostin expression in osteocytes and therefore releasing the wnt- $\beta$-catenin inhibition. In our mouse model, lack of PTH signaling in osteocytes is associated with an increase in sclerostin expression, inhibition of wnt- $\beta$-catenin and ultimately osteopenia. These findings are in agreement with recent studies of O'Brien et al. (2008), who demonstrated that mice expressing a constitutively active PPR receptor (Schipani et al. 1995, Calvi et al. 2001) specifically in osteocytes have a dramatic decrease in Sost expression and a $40 \%$ increase in BMD. Moreover, these transgenic mice could potentially rescue the osteopenic phenotype of $\mathrm{LRP} 5^{-/-}$ animals, if Lrp5 and/or 6 play direct roles in osteocyte biology. This would clearly indicate that osteocyte-derived sclerostin is indeed a negative regulator of wnt- $\beta$-catenin signaling. Recently, Yadav et al. (2008) reported that Lrp5 acts on bone via the regulation of serotonin synthesis in the gut and that the main action of LRP5 is in the duodenum. The authors demonstrated that LRP5 acts on serotonin-producing cells in the gut by blocking an enzyme that converts the amino acid tryptophan to serotonin. This new connection between bone and gut-derived serotonin, although shifting the action of LRP5 from osteoblasts to the duodenum, does not exclude that osteocyte-secreted sclerostin functions as a negative regulator of the wnt- $\beta$-catenin pathways in osteoblasts. Additional studies will be needed to investigate the role of serotonin in osteocytes.

Interestingly, the Ocy-PPR ${ }^{\mathrm{cKO}}$ mice also demonstrated hypocalcemia when challenged with a low-calcium diet, suggesting an important role of osteocytes in regulating calcium ion homeostasis. Normally, this low-calcium diet is easily corrected by increased PTH production and increased remodeling to bring the calcium back to normal. However, when osteocytes lack a functional PPR, this does not happen. This suggests that the osteocyte might be important in regulating calcium through $\mathrm{PTH}$ signaling. The role of osteocytes in controlling calcium homeostasis is controversial. Osteocytes clearly express high levels of receptors for PTH, and the osteocyte lacuno-canalicular network constitutes a microcirculatory system for calcium-containing periosteocytic fluid that is distinct from blood plasma and lymph fluid (Knothe Tate 2003). The osteocyte network represents an enormous surface area over which the cells interface with the surrounding matrix, useful for matrix mineral access (Cullinane 2002). Osteocytes can serve as key regulators of calcium homeostasis, are distributed widely in bone matrix, and are ideally situated to engage in systemic calcium homeostasis. Here, we report that mice lacking the PPR specifically in osteocytes have an impaired calcium homeostasis when subjected to a low-calcium diet and fail to properly respond to secondary hyperparathyroidism. These data support this hypothesis. However, it should be considered that three organs participate in supplying calcium to the blood: i) the small intestine, through the absorption of calcium from the diet (vitamin D-dependent); ii) the kidney, through the reabsorption of calcium from the glomerular filtrate; and iii) the skeleton, with the release of calcium from the bone. PTH acts directly, or indirectly, on these target organs, but the mechanism by which the hormone rapidly (within 1-2 h) increases blood calcium concentration is not completely understood. Several hypotheses have been 
postulated, which include an increase in renal calcium reabsorption from the kidney, an increase in bone resorption, and/or an increase in intestinal calcium absorption. Finally, our data support the theory that a release of calcium from the osteocytic lacuno-canalicular network may also be very important in this process, and regulated by PTH.

In summary, we have generated mice in which the PPR can be specifically ablated from osteocytes upon tamoxifen administration. These mice displayed mild osteopenia, tonic increase in Sost and sclerostin expression, and lack of PTH-induced Sost and sclerostin suppression. Moreover, Ocy-PPR ${ }^{\mathrm{cKO}}$ mice were unable to maintain a normal calcium plasma level when subjected to a low-calcium diet.

\section{Supplementary data}

This is linked to the online version of the paper at http://dx.doi.org/10.1530/ JOE-10-0308.

\section{Declaration of interest}

The authors declare that there is no conflict of interest that could be perceived as prejudicing the impartiality of the research reported.

\section{Funding}

This work was supported by the National Institutes of Health grants DK079161 (P D P), P01AR46798 (S E H), and by an MGH-ECOR Interim grant (P D P).

\section{Author contribution statement}

P D P, W F P, and F R B planned and designed the experiments; W F P, K J $\mathrm{B}$, and $\mathrm{P} \mathrm{D} \mathrm{P}$ performed the experiments; I $\mathrm{T}$ performed the immunohistochemical analysis. $\mathrm{T} K$ provided the $\mathrm{PPR}^{\mathrm{f} / \mathrm{fl}}$ mice; $\mathrm{S} \mathrm{H} E$ provided the $10 \mathrm{~kb}-D m p 1-C r e-E R T 2$ plasmid; P D P and W F P analyzed the data. P D P, W F P, and F R B wrote the manuscript.

\section{References}

Aguirre JI, Plotkin LI, Stewart SA, Weinstein RS, Parfitt AM, Manolagas SC \& Bellido T 2006 Osteocyte apoptosis is induced by weightlessness in mice and precedes osteoclast recruitment and bone loss. Journal of Bone and Mineral Research 21 605-615. (doi:10.1359/jbmr.060107)

Ai M, Holmen SL, Van Hul W, Williams BO \& Warman ML 2005 Reduced affinity to and inhibition by DKK1 form a common mechanism by which high bone mass-associated missense mutations in LRP5 affect canonical Wnt signaling. Molecular and Cellular Biology 25 4946-4955. (doi:10.1128/ MCB.25.12.4946-4955.2005)

van Bezooijen RL, Roelen BA, Visser A, van der Wee-Pals L, de Wilt E, Karperien M, Hamersma H, Papapoulos SE, ten Dijke P \& Lowik CW 2004 Sclerostin is an osteocyte-expressed negative regulator of bone formation, but not a classical BMP antagonist. Journal of Experimental Medicine 199 805-814. (doi:10.1084/jem.20031454)

van Bezooijen RL, ten Dijke P, Papapoulos SE \& Lowik CW 2005 $\mathrm{SOST} /$ sclerostin, an osteocyte-derived negative regulator of bone formation. Cytokine and Growth Factor Reviews 16 319-327. (doi:10.1016/ j.cytogfr.2005.02.005)
Bouxsein ML, Boyd SK, Christiansen BA, Guldberg RE, Jepsen KJ \& Muller R 2010 Guidelines for assessment of bone microstructure in rodents using micro-computed tomography. Journal of Bone and Mineral Research 25 1468-1486. (doi:10.1002/jbmr.141)

Calvi LM, Sims NA, Hunzelman JL, Knight MC, Giovannetti A, Saxton JM, Kronenberg HM, Baron R \& Schipani E 2001 Activated parathyroid hormone/parathyroid hormone-related protein receptor in osteoblastic cells differentially affects cortical and trabecular bone. Journal of Clinical Investigation 107 277-286. (doi:10.1172/JCI11296)

Cullinane DM 2002 The role of osteocytes in bone regulation: mineral homeostasis versus mechanoreception. Journal of Musculoskeletal and Neuronal Interactions 2 242-244.

Divieti P, Inomata N, Chapin K, Singh R, Juppner H \& Bringhurst FR 2001 Receptors for the carboxyl-terminal region of pth(1-84) are highly expressed in osteocytic cells. Endocrinology 142 916-925. (doi:10.1210/en.142.2.916)

Divieti P, Geller AI, Suliman G, Juppner H \& Bringhurst FR 2005 Receptors specific for the carboxyl-terminal region of parathyroid hormone on bonederived cells: determinants of ligand binding and bioactivity. Endocrinology 146 1863-1870. (doi:10.1210/en.2004-1262)

Ehrlich PJ, Noble BS, Jessop HL, Stevens HY, Mosley JR \& Lanyon LE 2002 The effect of in vivo mechanical loading on estrogen receptor $\alpha$ expression in rat ulnar osteocytes. Journal of Bone and Mineral Research 17 1646-1655. (doi:10.1359/jbmr.2002.17.9.1646)

Feng JQ, Ward LM, Liu S, Lu Y, Xie Y, Yuan B, Yu X, Rauch F, Davis SI, Zhang S et al. 2006 Loss of DMP1 causes rickets and osteomalacia and identifies a role for osteocytes in mineral metabolism. Nature Genetics $\mathbf{3 8}$ 1310-1315. (doi:10.1038/ng1905)

Fermor B \& Skerry TM 1995 PTH/PTHrP receptor expression on osteoblasts and osteocytes but not resorbing bone surfaces in growing rats. Journal of Bone and Mineral Research 10 1935-1943. (doi:10.1002/jbmr.5650101213)

George A, Gui J, Jenkins NA, Gilbert DJ, Copeland NG \& Veis A 1994 In situ localization and chromosomal mapping of the AG1 (Dmp1) gene. Journal of Histochemistry and Cytochemistry 42 1527-1531. (doi:10.1177/42.12.7983353)

Gong Y, Slee RB, Fukai N, Rawadi G, Roman-Roman S, Reginato AM, Wang H, Cundy T, Glorieux FH, Lev D et al. 2001 LDL receptor-related protein 5 (LRP5) affects bone accrual and eye development. Cell 107 513-523. (doi:10.1016/S0092-8674(01)00571-2)

Gowen LC, Petersen DN, Mansolf AL, Qi H, Stock JL, Tkalcevic GT, Simmons HA, Crawford DT, Chidsey-Frink KL, Ke HZ et al. 2003 Targeted disruption of the osteoblast/osteocyte factor 45 gene (OF45) results in increased bone formation and bone mass. Journal of Biological Chemistry 278 1998-2007. (doi:10.1074/jbc.M203250200)

Holmbeck K, Bianco P, Caterina J, Yamada S, Kromer M, Kuznetsov SA, Mankani M, Robey PG, Poole AR, Pidoux I et al. 1999 MT1-MMPdeficient mice develop dwarfism, osteopenia, arthritis, and connective tissue disease due to inadequate collagen turnover. Cell 99 81-92. (doi:10. 1016/S0092-8674(00)80064-1)

Holmbeck K, Bianco P, Pidoux I, Inoue S, Billinghurst RC, Wu W, Chrysovergis K, Yamada S, Birkedal-Hansen H \& Poole AR 2005 The metalloproteinase MT1-MMP is required for normal development and maintenance of osteocyte processes in bone. Journal of Cell Science $\mathbf{1 1 8}$ 147-156. (doi:10.1242/jcs.01581)

Jessop HL, Suswillo RF, Rawlinson SC, Zaman G, Lee K, Das-Gupta V, Pitsillides AA \& Lanyon LE 2004 Osteoblast-like cells from estrogen receptor $\alpha$ knockout mice have deficient responses to mechanical strain. Journal of Bone and Mineral Research 19 938-946. (doi:10.1359/jbmr.2004. 19.6.938)

Jilka RL, Weinstein RS, Bellido T, Parfitt AM \& Manolagas SC 1998 Osteoblast programmed cell death (apoptosis): modulation by growth factors and cytokines. Journal of Bone and Mineral Research 13 793-802. (doi:10.1359/jbmr.1998.13.5.793)

Jilka RL, Weinstein RS, Bellido T, Roberson P, Parfitt AM \& Manolagas SC 1999 Increased bone formation by prevention of osteoblast apoptosis with parathyroid hormone. Journal of Clinical Investigation 104 439-446. (doi:10. 1172/JCI6610)

Juppner H, Abou-Samra AB, Freeman M, Kong XF, Schipani E, Richards J, Kolakowski LF Jr, Hock J, Potts JT Jr, Kronenberg HM et al. 1991 
A $G$ protein-linked receptor for parathyroid hormone and parathyroid hormone-related peptide. Science 254 1024-1026. (doi:10.1126/science. 1658941)

Knothe Tate ML 2003 "Whither flows the fluid in bone?" An osteocyte's perspective Journal of Biomechanics 36 1409-1424. (doi:10.1016/S00219290(03)00123-4)

Kobayashi T, Chung UI, Schipani E, Starbuck M, Karsenty G, Katagiri T, Goad DL, Lanske B \& Kronenberg HM 2002 PTHrP and Indian hedgehog control differentiation of growth plate chondrocytes at multiple steps. Development 129 2977-2986.

Kobayashi T, Soegiarto DW, Yang Y, Lanske B, Schipani E, McMahon AP \& Kronenberg HM 2005 Indian hedgehog stimulates periarticular chondrocyte differentiation to regulate growth plate length independently of PTHrP. Journal of Clinical Investigation 115 1734-1742. (doi:10.1172/ JCI24397)

Lanyon L, Armstrong V, Ong D, Zaman G \& Price J 2004 Is estrogen receptor $\alpha$ key to controlling bones' resistance to fracture? Journal of Endocrinology 182 183-191. (doi:10.1677/joe.0.1820183)

Lee KC, Jessop H, Suswillo R, Zaman G \& Lanyon LE 2004 The adaptive response of bone to mechanical loading in female transgenic mice is deficient in the absence of oestrogen receptor- $\alpha$ and $-\beta$. Journal of Endocrinology 182 193-201. (doi:10.1677/joe.0.1820193)

Liu S, Zhou J, Tang W, Jiang X, Rowe DW \& Quarles LD 2006 Pathogenic role of Fgf 23 in Hyp mice. American Journal of Physiology. Endocrinology and Metabolism 291 E38-E49. (doi:10.1152/ajpendo.00008.2006)

Lorenz-Depiereux B, Bastepe M, Benet-Pages A, Amyere M, Wagenstaller J, Muller-Barth U, Badenhoop K, Kaiser SM, Rittmaster RS, Shlossberg AH et al. 2006 DMP1 mutations in autosomal recessive hypophosphatemia implicate a bone matrix protein in the regulation of phosphate homeostasis. Nature Genetics 38 1248-1250. (doi:10.1038/ng1868)

O'Brien CA, Plotkin LI, Vyas K, Cazer PE, Gortazar AR, Goellner JJ, Chen J, Shelton R, Weinstein RS, Schipani E et al. 2006 Activation of PTH receptor 1 specifically in osteocytes suppresses sost expression and increases bone mass in transgenic mice. In American Society for Bone and Mineral Research. Ed JoBaM Research. Philadelphia, PA 21 S4.

O'Brien CA, Plotkin LI, Galli C, Goellner JJ, Gortazar AR, Allen MR, Robling AG, Bouxsein M, Schipani E, Turner CH et al. 2008 Control of bone mass and remodeling by PTH receptor signaling in osteocytes. PLoS ONE 3 e2942. (doi:10.1371/journal.pone.0002942)

Petersen DN, Tkalcevic GT, Mansolf AL, Rivera-Gonzalez R \& Brown TA 2000 Identification of osteoblast/osteocyte factor 45 (OF45), a bonespecific cDNA encoding an RGD-containing protein that is highly expressed in osteoblasts and osteocytes. Journal of Biological Chemistry 275 36172-36180. (doi:10.1074/jbc.M003622200)
Schipani E, Kruse K \& Juppner H 1995 A constitutively active mutant PTH-PTHrP receptor in Jansen-type metaphyseal chondrodysplasia. Science 268 98-100. (doi:10.1126/science.7701349)

Schipani E, Lanske B, Hunzelman J, Luz A, Kovacs CS, Lee K, Pirro A, Kronenberg HM \& Juppner H 1997 Targeted expression of constitutively active receptors for parathyroid hormone and parathyroid hormone-related peptide delays endochondral bone formation and rescues mice that lack parathyroid hormone-related peptide. PNAS 94 13689-13694. (doi:10. 1073/pnas.94.25.13689)

Soriano P 1999 Generalized lacZ expression with the ROSA26 Cre reporter strain. Nature Genetics 21 70-71. (doi:10.1038/5007)

Tatsumi S, Ishii K, Amizuka N, Li M, Kobayashi T, Kohno K, Ito M, Takeshita S \& Ikeda K 2007 Targeted ablation of osteocytes induces osteoporosis with defective mechanotransduction. Cell Metabolism $\mathbf{5}$ 464-475. (doi:10.1016/j.cmet.2007.05.001)

Westbroek I, De Rooij KE \& Nijweide PJ 2002 Osteocyte-specific monoclonal antibody MAb OB7.3 is directed against Phex protein. Journal of Bone and Mineral Research 17 845-853. (doi:10.1359/jbmr.2002. 17.5.845)

Winkler DG, Sutherland MK, Geoghegan JC, Yu C, Hayes T, Skonier JE, Shpektor D, Jonas M, Kovacevich BR, Staehling-Hampton K et al. 2003 Osteocyte control of bone formation via sclerostin, a novel BMP antagonist. EMBO Journal 22 6267-6276. (doi:10.1093/emboj/cdg599)

Yadav VK, Ryu J-H, Suda N, Tanka K, Gingrich JA, Shutz G, Glorieux FH, Chaing CY, Zajac JD, Insogna KI et al. 2008 Lrp5 controls bone formation by inhibiting serotonin synthesis in the duodenum. Cell 135 825-837. (doi:10.1016/j.cell.2008.09.059)

Yang W, Lu Y, Kalajzic I, Guo D, Harris MA, Gluhak-Heinrich J, Kotha S, Bonewald LF, Feng JQ, Rowe DW et al. 2005 Dentin matrix protein 1 gene cis-regulation: use in osteocytes to characterize local responses to mechanical loading in vitro and in vivo. Journal of Biological Chemistry 280 20680-20690.

Ye L, MacDougall M, Zhang S, Xie Y, Zhang J, Li Z, Lu Y, Mishina Y \& Feng JQ 2004 Deletion of dentin matrix protein-1 leads to a partial failure of maturation of predentin into dentin, hypomineralization, and expanded cavities of pulp and root canal during postnatal tooth development. Journal of Biological Chemistry 279 19141-19148. (doi:10.1074/jbc. M400490200)

Received in final form 22 December 2010

Accepted 10 January 2011

Made available online as an Accepted Preprint 10 January 2011 